\title{
A arte da mudança e das adaptações
}

Qualquer livro texto sobre orientação empresarial e/ou profissional ressaltará a capacidade de mudança e adaptação como uma das maiores qualidades de uma pessoa e/ou empresa. Na verdade, em todos os ramos de nossas vidas esta qualidade é requerida. A enxurrada de novos conceitos, a que diariamente estamos expostos, praticamente nos conduz à necessidade de mudanças.

Mais do que saber mudar e se adaptar, é importante identificar o momento mais oportuno e fazê-lo com arte, para que tudo ocorra com suavidade. Assim, com o passar do tempo, será perceptivel a alteração, mas sem choques ou traumas.

Para os leitores da Revista Dental Press de Ortodontia e Ortopedia Facial, fica fácil perceber um exemplo claro disto. A cada nova edição pode-se notar o quanto este veículo se tornou cientificamente "de peso". Todo o quadro editorial, junto aos consultores, tem obtido progressivamente mais êxito na orientação e seleção dos artigos. E esta tarefa também torna-se cada vez mais fácil, em virtude do significante aumento da qualidade dos artigos submetidos para publicação. Esta qualidade inclui o tema e o desenho metodológico dos trabalhos, bem como a objetividade com que são apresentados.

Há exatos dois anos, assumimos o editorial desta revista, com o compromisso de conduzi-la na direção de um rigor científico cada vez maior. Estamos num processo de mudança, ainda adequando trabalhos um pouco mais extensos, para um formato mais compacto, mas sem perder seus conceitos. Nas próximas edições, gradualmente, estes serão ajustados para formatos ainda mais compactos, sem perder qualidade, permitindo um maior número de trabalhos.

Como um termômetro deste aumento de informação, desde que iniciamos em 1996 (naquela época como membro do conselho), o número de artigos por edição triplicou. Trabalho este que vem sendo realizado incansavelmente, sendo que hoje podemos comemorar o marco de 70 artigos por ano. Vale ressaltar que o número de artigos sugerido para a área da saúde por um dos mais rigorosos órgãos de divulgação científica da América Latina, o SciELO (Scientific Eletronic Library Online), é de 60 por ano.

Assim, o aumento da produtividade, decorrente da quantidade de pesquisas com qualidade, gradualmente alimenta o fluxo de publicação, bem como os leitores podem contar com um maior número de artigos interessantes a cada exemplar da revista.

Nesta edição incorporamos a formatação estruturada do resumo e do abstract, que conta com a divisão por partes dos dados do resumo do trabalho. Desta forma, seguindo uma tendência internacional, os dados são apresentados mais objetivamente, bem como direcionam os autores a incluir as informações imprescindiveis referentes ao trabalho.

Também iniciamos uma política de escolher, dentre todos os artigos da revista (o que é uma tarefa difícil), aquele que receberá um "selo" de destaque, nomeado "selecionado pelo editor". Esta iniciativa visa estimular os leitores e autores, a exemplo de vários segmentos produtivos da sociedade, a uma busca por qualidade. É claro que a própria impressão de um artigo na revista já o premia pela qualidade, portanto todos já merecem ser compartilhados com a comunidade ortodôntica. Mas sempre elegeremos um deles por edição, com todo o respeito e mérito aos outros.

Nesta edição de final de ano, contamos com uma franca, clara e objetiva conversa com o Dr. Messias Rodrigues, que retrata sua simplicidade como excelente clínico e professor que é, com a participação dos convidados entrevistadores: Dr. Interlandi, Dr. Cabrera, Dr. Júlio Vargas Neto, Dra. Rosana Villela e Dr. Korrodi Ritto, que é um ilustre professor em Portugal.

Estão entre os artigos deste número o debate sobre a polêmica da alteração da altura facial anterior inferior (AFAI) entre casos com e sem exodontias de pré-molares, assim como, em outra pesquisa, as diferenças entre os gêneros e raças. Num outro artigo, discutem-se os valores adotados para as inclinações normais dos incisivos, que são utilizados na prescrição de braquetes padrão de Andrews, para uma amostra de brasileiros. Também são apresentados os efeitos verticais e transversais da expansão rápida da maxila vistos na radiografia frontal, o uso de marcadores metálicos encaixados nos acessórios ortodônticos para pesquisas radiográficas, prevalência das más oclusões, avaliação crítica de sobreposições radiográficas totais, alterações funcionais dos pacientes com Classe III e orientações legais para os cirurgiões ortognatas e ortodontistas.

$\mathrm{O}$ artigo que recebeu o selo de "selecionado pelo editor" nesta edição versa sobre os efeitos do aparelho de Herbst na dentadura mista. Trata-se de um assunto polêmico (o avanço mandibular precoce), sobre o qual o leitor, após o exame deste trabalho que apresenta um desenho metodológico ponderado, poderá obter suas impressões para avaliar a relação custo-benefício da aplicação clínica desta abordagem.

Com a aproximação do final de mais um ano, em nome de toda a equipe que participa das edições da Revista Dental Press de Ortodontia e Ortopedia Facial, desejo um Natal abençoado a todos, e que 2006 propicie avanços em todas as áreas de nossas vidas!

Adilson Luiz Ramos 